\title{
Access to antibiotics in New Delhi, India: implications for antibiotic policy
}

Anita Kotwani ${ }^{1 *}$ and Kathleen Holloway ${ }^{2}$

\begin{abstract}
Objective: The present survey was conducted to investigate the price and availability of a basket of 24 essential antibiotics and eight high-end antibiotics at various levels of health care in public and private sector in National Capital Territory of Delhi, India using standardized WHO/HAl methodology.

Methods: Data on procurement price and availability was collected from three public healthcare providers in the state: the federal (central) government, state government and Municipal Corporation of Delhi (MCD). Overall a total of 83 public facilities, 68 primary care, 10 secondary cares and 5 tertiary care facilities were surveyed. Data was also collected from private retail $(n=40)$ and chain pharmacies $(n=40)$ of a leading corporate house. Prices were compared to an international reference price (expressed as median price ratio-MPR).

Results: Public sector: Delhi state government has its essential medicine list (Delhi state EML) and was using Delhi state EML 2007 for procurement; the other two agencies had their own procurement list. All the antibiotics procured including second and third generation antibiotics except for injections were available at primary care facilities. Antibiotic available were on the basis of supply rather than rationality or the Delhi state EML and none was 100\% available. There was sub-optimal availability of some essential antibiotics while other non-essential ones were freely available. Availability of antibiotics at tertiary care facilities was also sub-optimal. Private sector: Availability of antibiotics was good. For most of the antibiotics the most expensive and popular trade names were often available. High-end antibiotics, meropenam, gemifloxacin, and moxifloxacin were commonly available. In retail pharmacies some newer generation non-essential antibiotics like gemifloxacin were priced lower than the highest-priced generic of amoxicillin + clavulanic acid, azithromycin, and cefuroxime aexitl.

Conclusions: Inappropriate availability and pricing of newer generation antibiotics, which may currently be bought without prescription, is likely to lead to their over-use and increased resistance. All providers should follow the EML of whichever of the three concerned Delhi public sector agencies that it is under and these EMLs should follow the essential medicine concept. The Indian regulatory authorities need to consider urgently, drug schedules and pricing policies that will curtail inappropriate access to new generation antibiotics.
\end{abstract}

Keywords: Access, Antibiotics, Antibiotic availability, Antibiotic price, Primary care, Public health sector, Private retail pharmacies, Procurement price

\section{Introduction}

Antimicrobial resistance (AMR) is rapidly increasing globally, therefore suitable policy and actions are urgently needed to combat AMR [1]. The widely held consensus for the rapid increase in development of AMR is over-prescribing and inappropriate use of antibiotics $[2,3]$. This consensus leads in turn to the need for having

\footnotetext{
* Correspondence: anitakotwani@gmail.com

${ }^{1}$ Department of Pharmacology, V. P. Chest Institute, University of Delhi, Delhi, India Full list of author information is available at the end of the article
}

an antibiotic policy that should ensure critical selection and appropriate use of antibiotics [4]. Since health systems and prescribing behavior are varied and complex, a nationally or locally coordinated antibiotic policy, contextualized to the particular country/region, will be needed to have any substantial impact on appropriate antibiotic use.

The first step in combating inappropriate use of antibiotics is to measure access and use of antibiotic in order to quantify the scale of the problem and to have a
C Biomed Central 
baseline data to compare and evaluate the impact of any intervention. In a number of developed countries, extensive surveillance programs have been developed to study patterns of antibiotic use and guidelines for antibiotic use [5-7]. However, the ability to undertake such surveillance is lacking in resource-constrained settings. The problem of AMR, appropriate availability and inappropriate use of antibiotics has received relatively little recognition in developing countries [8]. Recently, a few collaborative studies were conducted in India for developing a validated methodology for measuring consumption and antibiotic use in the community and hospital [8-10]. Overprescribing, misuse of antibiotics and low adherence to treatment guidelines were seen in both public and private settings [10-13]. However, there is no literature available in India on access, availability and price of various antibiotics at public and private retail pharmacies. Hence, the present reported survey was undertaken (July-October 2011) with the objective to study to measure the access of various antibiotics in public and private sectors in New Delhi using a standardized methodology of World Health Organization and Health Action International (WHO/HAI) [14]. The survey was undertaken with the ultimate objective to move towards enabling an antibiotic policy that will encourage availability of appropriate antibiotics (and not inappropriate ones) and hence their rational use at different level of healthcare.

\section{Methods}

\section{State background}

Delhi, the capital of India is known as the National Capital Territory of Delhi (NCT Delhi).

Three main public sector health care providers in NCT Delhi are: the Central (federal) Government under the Ministry of Health and Family Welfare (MoH\&FW), the Directorate of Health Services (DHS) in the Government of NCT (GNCT) Delhi and another public sector provider in Delhi city - the Municipal Corporation of Delhi (MCD). All citizens can visit and avail the free services in the facilities of the three public healthcare providers. All these public sectors have their own procurement systems and essential or procurement list of medicines.

In the private sector, recently, chain pharmacies have entered the Indian retail sector. Therefore, both types of retail pharmacies were included in the survey, the traditional private retail pharmacies and the chain pharmacies of a leading corporate house.

\section{Sampling}

This survey followed the WHO/HAI methodology [14] and was conducted in all eight districts of Delhi and surveyed five facilities in each district covering the entire Delhi state.

\section{Public sector}

Central procurement prices were collected from all the three centralized public sector procurement agencies/department of healthcare providers. Tertiary care facilities under central government (CG) also undertake independent medicine procurement to augment the supply from the central government procurement agency. Procurement prices were also collected from these tertiary care facilities; namely, Ram Manohar Lohia (RML) Hospital and Safdurjung Hospital (SH) which have common pooled procurement (labeled as CG1) and Lady Hardinge Medical College (LH) which has independent procurement (labeled as CG2).

Medicines are provided for free in all public facilities hence only antibiotic availability was collected from the various public facilities. For each district one secondary care hospital and four primary health care (dispensaries) were randomly selected. In one of the districts a tertiary care instead of secondary care hospital was enrolled. Overall a total of 83 facilities (40 facilities under GNCT, Delhi, 40 under MCD and 3 tertiary care facilities of CG) were surveyed (Table 1).

\section{Private sector}

The private sector samples were identified by selecting one retail pharmacy outlet in each sector that is geographically closest to each public outlet. In each district five retail pharmacies and five retail chain pharmacies were included. Thus a total of 80 facilities were surveyed.

\section{Antibiotics surveyed}

The WHO/HAI methodology identifies a basket of 30 core medicines - 14 essential medicines from global burden of diseases and 16 specific for a particular region, South East Asia. Of these 30 medicines, seven are antibiotics in different dosage forms (Table 2). To these core seven antibiotics, a supplementary list of 17 antibiotics from various classes were added as mentioned in Table 3 on the basis of their inclusion in Delhi State essential medicine list (EML). Also, a further eight high-end antibiotics (listed in the footnote of Table 3) were surveyed in secondary care and tertiary care public facilities and private sector pharmacies.

As per the WHO/HAI methodology [14] data was collected for both the originator brand, and the lowestpriced generic equivalent found at each medicine outlet. Until 2005, the Indian regulatory system recognized process patents not product patent and therefore all medicines that are manufactured in India are generic versions. However, all products carry a brand (trade) name [15]. Originators brands (OBs) in India do not have any additional recognition as originator brand. Often OBs are not available but the same molecules manufactured by 
Table 1 Number of facilities in each survey area under public and private sector

\begin{tabular}{|c|c|c|c|c|c|c|}
\hline \multirow[t]{2}{*}{ S.No } & \multirow{2}{*}{$\begin{array}{l}\text { Survey } \\
\text { area } \\
\text { District }\end{array}$} & \multicolumn{3}{|c|}{ Public sector* } & \multicolumn{2}{|c|}{ Private Sector\# } \\
\hline & & $\begin{array}{l}\text { National capital territory of } \\
\text { Delhi Government }\end{array}$ & $\begin{array}{c}\text { Central } \\
\text { government }\end{array}$ & $\begin{array}{c}\text { Municipal corporation of } \\
\text { Delhi }\end{array}$ & $\begin{array}{c}\text { Retail } \\
\text { pharmacy }\end{array}$ & $\begin{array}{l}\text { Retail chain } \\
\text { pharmacy }\end{array}$ \\
\hline 1 & Central & 5 & 2 & 5 & 5 & 5 \\
\hline 2 & South & 5 & 1 & 5 & 5 & 5 \\
\hline 3 & East & 5 & & 5 & 5 & 5 \\
\hline 4 & North & 5 & & 5 & 5 & 5 \\
\hline 5 & North East & 5 & & 5 & 5 & 5 \\
\hline 6 & North West & 5 & & 5 & 5 & 5 \\
\hline 7 & South West & 5 & & 5 & 5 & 5 \\
\hline \multirow[t]{3}{*}{8} & West & 5 & & 5 & 5 & 5 \\
\hline & Total & 40 & 3 & 40 & 40 & 40 \\
\hline & Grand total & & 83 & & \multicolumn{2}{|c|}{80} \\
\hline
\end{tabular}

*For public sector one version of each medicine, the lowest-priced generic (LPG) were collected for both price and availability as public sector procure only one generic version of each medicine.

\#For private sector, Seven core antibiotics were surveyed in three versions, Originator brand (OB), Highest-priced generic (HPG) and Lowest-priced generic (LPG); Seventeen supplementary antibiotics and eight high end antibiotics were surveyed in two versions, HPG and LPG.

other companies with different trade names, branded generics, are available. Therefore, for this survey, in addition to originator brand and lowest-priced generic (LPG) a third version, highest-priced generic (HPG) was added to find out the price and availability of seven core antibiotics available at each facility. For seventeen supplementary antibiotics and eight high-end antibiotics, two versions, highest-priced and lowest-priced generics were surveyed and found at each private facility (Table 1, 2, and 3).

Since the public sector has only one version of each medicine, only the lowest-priced generic (LPG) were collected for both price and availability.

Data collection, entry and analysis

Trained data collectors visited enrolled facilities with a standardized form and recorded the price and availability of each antibiotic medicine. For public sector, procurement price was collected from three central agencies Central procurement agency (CPA) for Delhi state

\begin{tabular}{|c|c|c|c|}
\hline $\begin{array}{l}\text { Antibiotic } \\
\text { no. }\end{array}$ & Antibiotic name & $\begin{array}{l}\text { Medicine } \\
\text { strength }\end{array}$ & $\begin{array}{l}\text { Dosage } \\
\text { form }\end{array}$ \\
\hline 1 & Amoxicillin & $500 \mathrm{mg}$ & cap/tab \\
\hline 2 & Amoxicillin suspension & $25 \mathrm{mg} / \mathrm{ml}$ & millilitre \\
\hline 3 & Ceftriaxone injection & $1 \mathrm{~g} / \mathrm{vial}$ & vial \\
\hline 4 & Ciprofloxacin & $500 \mathrm{mg}$ & cap/tab \\
\hline 5 & $\begin{array}{l}\text { Co-trimoxazole } \\
\text { suspension }\end{array}$ & $8+40 \mathrm{mg} / \mathrm{ml}$ & mililitre \\
\hline 6 & Doxycycline & $100 \mathrm{mg}$ & cap/tab \\
\hline 7 & Gentamicin eye drops & $0.3 \%$ & millilitre \\
\hline
\end{tabular}

Table 3 List of Seventeen antibiotics added

\begin{tabular}{|c|c|c|c|}
\hline $\begin{array}{l}\text { Antibiotic } \\
\text { no. }\end{array}$ & Antibiotic name & $\begin{array}{l}\text { Medicine } \\
\text { strength }\end{array}$ & $\begin{array}{l}\text { Dosage } \\
\text { form }\end{array}$ \\
\hline 1 & $\begin{array}{c}\text { Amoxicillin + Clavulanic } \\
\text { acid }\end{array}$ & $500 \mathrm{~g}+125 \mathrm{mg}$ & cap/tab \\
\hline 2 & Amoxicillin 250 & $250 \mathrm{mg}$ & Tab/cap \\
\hline 3 & $\begin{array}{c}\text { Amoxicillin + Clavulanic } \\
\text { acid Syrup }\end{array}$ & $\begin{array}{c}200 \mathrm{mg}+ \\
28.5 \mathrm{mg} / 5 \mathrm{ml}\end{array}$ & mililitre \\
\hline 4 & Ampicillin Suspension & $125 \mathrm{mg} / 5 \mathrm{ml}$ & mililitre \\
\hline 5 & Azithromycin & $500 \mathrm{mg}$ & Tab/cap \\
\hline 6 & $\begin{array}{c}\text { Benzathine Penicillin } \\
\text { Powder }\end{array}$ & 2.4MU/vial & vial \\
\hline 7 & Cefixime & $200 \mathrm{mg}$ & Tab/cap \\
\hline 8 & Cefuroxime axetil & $250 \mathrm{mg}$ & Tab/cap \\
\hline 9 & Cefuroxime Suspension & $125 \mathrm{mg} / 5 \mathrm{ml}$ & mililitre \\
\hline 10 & Cephalexin & $500 \mathrm{mg}$ & Tab/cap \\
\hline 11 & Cephalexin Syrup & $250 \mathrm{mg} / 5 \mathrm{ml}$ & mililitre \\
\hline 12 & $\begin{array}{l}\text { Erythromycin powder for } \\
\text { suspension }\end{array}$ & $125 \mathrm{mg} / 5 \mathrm{ml}$ & mililitre \\
\hline 13 & Erythromycin Stearate & $250 \mathrm{mg}$ & Tab/cap \\
\hline 14 & Gentamicin injection & $40 \mathrm{mg} / \mathrm{ml}$ & inj \\
\hline 15 & Norfloxacin & $400 \mathrm{mg}$ & Tab/cap \\
\hline 16 & Ofloxacin & $200 \mathrm{mg}$ & Tab/cap \\
\hline 17 & Roxithromycin & $50 \mathrm{mg}$ & Tab/cap \\
\hline $\begin{array}{l}\text { Additional lis } \\
\text { private pharn } \\
\text { 1. Meropener } \\
\text { 2. Imipenem } \\
\text { 3. Colistin inj } \\
\text { 4. Vancomyci } \\
\text { 5. Ceftazidim } \\
\text { 6. Cefepime } \\
\text { 7. Gemifloxac } \\
\text { 8. Moxifloxac }\end{array}$ & $\begin{array}{l}\text { of eight high-end antibiotics st } \\
\text { lacies. } \\
500 \mathrm{mg} \text { inj. } \\
\text { - cilastatin } 500 \mathrm{mg}+500 \mathrm{mg} \text { inj } \\
1,000,000 \mathrm{units} / \mathrm{vial} . \\
500 \mathrm{mg} \text { inj. } \\
1 \mathrm{~g} \mathrm{vial} \text {. } \\
\mathrm{g} \text { inj. } \\
\text { in } 320 \mathrm{mg} . \\
\text { n } 400 \mathrm{mg} \text {. }\end{array}$ & rveyed in hospitals & \\
\hline
\end{tabular}


government (GNCT, Delhi); procurement department of MCD; and Medical Stores Organization (MSO), procurement department of CG. Procurement price was also collected from two decentralized sites of central government hospitals - CG1 (RML/SH) and CG2 (LH).

Medicine unit prices were entered into Excel spreadsheets with double entry, auto-checking, and automated analysis feature of the workbook developed by $\mathrm{WHO} /$ HAI [14]. To facilitate international comparisons, antibiotic prices are expressed as median price ratio (MPR) [16]. The MPR is the local median unit price of a medicine in comparison with the median unit price found in the Management Sciences for Health (MSH) Price Indicator Guide, 2010 [17].

\section{Ethical approval}

Ethical approval of the study was obtained from Vallabhbhai Patel Chest Institute, University of Delhi, India. Permission for data collection was obtained from Health
Department, Directorate Health Services (DHS) of Government of NCT Delhi, Municipal Corporation of Delhi, and from Ministry of Health \& Family Welfare, Government of India.

\section{Results}

\section{Public sector}

Procurement prices

The median MPR of each antibiotic surveyed, whether it is on the Delhi state EML and which procurement agencies procured these antibiotics are shown in Table 4. The 2007 Delhi sate EML was used for purchase of medicines for Delhi state run facilities at the time of the survey in 2011 [18]. Out of 24 antibiotics surveyed, 20 antibiotics were on Delhi state EML used by the CPA, the GNCT, Delhi procurement agency, which was procuring all antibiotics on the list except benzathine penicillin. The other two public sector procurement agencies did not have their own EML but had their list

Table 4 Median price ratios (MPRs) of surveyed antibiotics in various public sector procurement agencies in Delhi

\begin{tabular}{|c|c|c|c|c|}
\hline Antibiotic no. & Medicine name & Delhi state EML 2007 & Median MPR & Procurement agencies \\
\hline 1 & Amoxicillin + Clavulanic acid 500 mg + 125 mg cap/tab & No & 0.91 & MCD, CG1,CG2 \\
\hline 2 & Amoxicillin 500 mg cap/tab & Yes & 1.22 & $\mathrm{MCD}, \mathrm{CG} 2, \mathrm{CPA}$ \\
\hline 3 & Amoxicillin $250 \mathrm{mg}$ cap/tab & Yes & 1.11 & $\mathrm{MCD}, \mathrm{CG} 1, \mathrm{CG} 2, \mathrm{CPA}$ \\
\hline 4 & Amoxicillin suspension $25 \mathrm{mg} / \mathrm{ml}$ & Yes & 1.04 & $\mathrm{MCD}, \mathrm{CG} 1, \mathrm{CG} 2, \mathrm{CPA}$ \\
\hline 5 & Amoxicillin + Clavulanic acid Syrup 200 mg + 28.5 mg/5 ml & No & * & MSO,MCD \\
\hline 6 & Ampicillin Suspension $125 \mathrm{mg} / 5 \mathrm{ml}$ & Yes & 0.97 & CPA \\
\hline 7 & Azithromycin 500 mg cap/tab & No & 0.53 & $\mathrm{MCD}, \mathrm{CG} 2$ \\
\hline 8 & Benzathine Penicillin Powder 2.4MU/vial & Yes & 0.48 & CG1 \\
\hline 9 & Cefixime $200 \mathrm{mg}$ cap/tab & No & 0.54 & MCD \\
\hline 10 & Ceftriaxone injection $1 \mathrm{~g} / \mathrm{vial}$ & Yes & 0.50 & MSO, MCD, CG1,CG2, CPA \\
\hline 11 & Cefuroxime axetil 250 mg cap/tab & Yes & 0.64 & $\mathrm{MSO}, \mathrm{MCD}, \mathrm{CPA}$ \\
\hline 12 & Cefuroxime Suspension $125 \mathrm{mg} / 5 \mathrm{ml}$ & Yes & 0.43 & CPA \\
\hline 13 & Cephalexin 500 mg cap/tab & Yes & 0.83 & $\mathrm{MCD}, \mathrm{CG} 1, \mathrm{CPA}$ \\
\hline 14 & Cephalexin Syrup 250 mg/5 ml & Yes & 0.68 & $\mathrm{MSO}, \mathrm{CG} 2, \mathrm{CPA}$ \\
\hline 15 & Ciprofloxacin 500 mg cap/tab & Yes & 0.88 & $\mathrm{MCD}, \mathrm{CG} 1, \mathrm{CG} 2, \mathrm{CPA}$ \\
\hline 16 & Co-trimoxazole suspension $8+40 \mathrm{mg} / \mathrm{ml}$ & Yes & 0.76 & $\mathrm{MCD}, \mathrm{CG} 1, \mathrm{CG} 2, \mathrm{CPA}$ \\
\hline 17 & Doxycycline 100 mg cap/tab & Yes & 1.11 & $\mathrm{MCD}, \mathrm{CG} 2, \mathrm{CPA}$ \\
\hline 18 & Erythromycin powder for suspension $125 \mathrm{mg} / 5 \mathrm{ml}$ & Yes & 0.67 & $\mathrm{CG} 1, \mathrm{CG} 2, \mathrm{CPA}$ \\
\hline 19 & Erythromycin Stearate $250 \mathrm{mg}$ cap/tab & Yes & 1.03 & $\mathrm{MSO}, \mathrm{MCD}, \mathrm{CG} 1, \mathrm{CG} 2, \mathrm{CPA}$ \\
\hline 20 & Gentamicin eye drops $0.3 \%$ & Yes & 0.44 & $\mathrm{MCD}, \mathrm{CG} 1, \mathrm{CG} 2, \mathrm{CPA}$ \\
\hline 21 & Gentamicin injection $40 \mathrm{mg} / \mathrm{ml}$ & Yes & 0.77 & $\mathrm{MCD}, \mathrm{CG} 1, \mathrm{CG} 2, \mathrm{CPA}$ \\
\hline 22 & Norfloxacin 400 mg cap/tab & Yes & 0.75 & $\mathrm{MCD}, \mathrm{CG} 1, \mathrm{CG} 2, \mathrm{CPA}$ \\
\hline 23 & Ofloxacin $200 \mathrm{mg}$ cap/tab & Yes & 0.59 & $\mathrm{MSO}, \mathrm{MCD}, \mathrm{CG} 1, \mathrm{CG} 2, \mathrm{CPA}$ \\
\hline 24 & Roxithromycin $50 \mathrm{mg}$ cap/tab & Yes & * & MSO,MCD,CPA \\
\hline
\end{tabular}

MSO Medical store organization, the procurement agency for central government hospitals, MCD Municipal corporation of Delhi, CG1 decentralized procurement done by two tertiary care hospitals of central government, CG2 decentralized procurement done by single tertiary care hospital of central government, CPA the procurement agency for Government of National Capital Territory of Delhi.

* MSH price is not available therefore MRP can not be calculated. 
of medicines for procurement prepared by their institute committee.

A few antibiotics, e.g., azithromycin, ceftriaxone injection, erythromycin, gentamicin eye drops, gentamicin injection, and roxithromycin were found to have large variation in procurement price by different agencies (Table 5). Usually the highest procurement price for these medicines was for the tertiary care facilities (CG2 and CG1) doing independent procurement and the least price was for CPA-GNCT, Delhi which manages pooled procurement for all the facilities under the Delhi state government.

\section{Availability of surveyed antibiotics}

Table 6 depicts the availability of surveyed antibiotics in primary care (dispensaries), secondary care hospitals and tertiary care level of hospital under Delhi state government, (GNCT, Delhi) and under Municipal Corporation of Delhi (MCD). Three antibiotics which were not in Delhi State EML were found: amoxicillin + clavulanic acid tablet was available at all three levels of health care of Delhi State and MCD and 2 out of three tertiary care facilities of Central Government (CG). Amoxicillin + clavulanic acid syrup and cefixime was available at primary and secondary care facilities of GNCT, Delhi and MCD and only at one tertiary care facility of MCD.

Antibiotics with more than $80 \%$ availability at GNCT, Delhi-run primary care were: amoxicillin500 $\mathrm{mg}$ and norfloxacin tablets. Antibiotics with more than $80 \%$ availability at MCD run primary care were none and at secondary care were ciprofloxacin and doxycycline. The availability of some essential antibiotics e.g. ampicillin suspension, erythromycin suspension and tablets for primary care were sub-optimal, particularly in MCD.

Table 7 shows availability of antibiotics in tertiary care facilities of Central Government. Four antibiotics amoxicillin $250 \mathrm{mg}$, ciprofloxacin, erythromycin stearate, and norfloxacin for OPD patients and two injections ceftriaxone and gentamicin were available in all three tertiary care facilities. By contrast some essential antibiotics e.g. amoxicillin suspension, doxycycline and cephalexin were poorly available.

\section{Private sector \\ Price-to-patient}

The median MPR for all versions, minimum and maximum MPR found at retail pharmacies and median unit price in local currency is shown in Table 8. Findings were similar at retail chain pharmacies, except for a few antibiotics, like amoxicillin suspension, cephalexin syrup, and gentamicin eye drops whose median MPRs were found to be little less and for few antibiotics, like ciprofloxacin, doxycycline, median MPRs a little more than the median MPRs found at private retail pharmacies.

\section{Price variation between highest and lowest generic}

For certain medicines huge price variation was observed for highest-priced and lowest-priced generic available at the surveyed retail facilities. The mean MPR of highest and lowest-priced generic is shown in Figure 1 and the highest variation of 5.1 times was seen for doxycycline, followed by amoxicillin + clavulanic acid tablet (3.3 times).

\section{Overall availability}

Except for two antibiotics all other antibiotics were available in the private sector (Table 8). If only one version of the medicine (apart from originator for seven core medicines) was available then that medicine's name and price became the lowest-priced generic available. Results were similar at chain pharmacies although the availability of certain antibiotics like cephalexin was more at chain pharmacies.

\section{Antibiotics with very poor availability}

The two antibiotics that had very poor or no availability $\{0.0 \%-2.5 \%$ in any version (OB or generic) $\}$, were, ampicillin suspension and benzathine penicillin powder. Both the antibiotics are included in the Delhi state EML.

Table 5 Variation in unit procurement price in local currency (INR) of few antibiotics by different procurement agencies in New Delhi

\begin{tabular}{llllll}
\hline Antibiotic name & MSO(central government & MCD & CG1 & CG2 & CPA(Delhi state government) \\
\hline Azithromycin cap/tab & No rate available & 6.31 & No rate available & 9.45 & 15.50 \\
Ceftriaxone injection & 14.99 & 18.28 & 16.46 & 1.68 & 8.50 \\
Erythromycin Stearate & 1.43 & 1.32 & 2.04 & & 0.85 \\
cap/tab & & & 1.21 & 0.58 \\
Gentamicin eye drops & No rate available & 0.61 & 0.81 & 2.49 & 1.52 \\
Gentamicin injection & No rate available & 1.40 & 1.53 & No rate available & 0.74
\end{tabular}

MSO Medical store organization, the procurement agency for central government hospitals, MCD Municipal corporation of Delhi, CG1 decentralized procurement done by two tertiary care hospitals of central government, CG2 decentralized procurement done by single tertiary care hospital of central government, CPA the procurement agency for Government of National Capital Territory of Delhi, INR Indian Rupees, Local currency. 
Table 6 Availability of surveyed antibiotics in primary, secondary and tertiary care facilities of two public sectors in Delhi, India

\begin{tabular}{|c|c|c|c|c|c|c|}
\hline \multirow[t]{2}{*}{ Antibiotic name } & \multicolumn{3}{|c|}{ GNCT Delhi } & \multicolumn{3}{|c|}{ MCD } \\
\hline & $\begin{array}{l}\text { Pr. care } \\
(n=32)\end{array}$ & $\begin{array}{l}\text { Second care } \\
\qquad(n=7)\end{array}$ & $\begin{array}{c}\text { Tertiary care } \\
\qquad(n=1)\end{array}$ & $\begin{array}{l}\text { Pr. care } \\
(n=36)\end{array}$ & $\begin{array}{l}\text { Second care } \\
\qquad(n=3)\end{array}$ & $\begin{array}{c}\text { Tertiary care } \\
(n=1)\end{array}$ \\
\hline 1. amoxicillin $250+$ clavulanic acid\$ & $21.9 \%$ & $42.9 \%$ & Available & $52.8 \%$ & $66.7 \%$ & Available \\
\hline 2. Amoxicillin 250\# & $71.9 \%$ & $57.1 \%$ & Available & $19.4 \%$ & $33.3 \%$ & N.A \\
\hline 3. Amoxicillin 500\# & $81.3 \%$ & $85.7 \%$ & Available & $30.6 \%$ & $66.7 \%$ & Available \\
\hline 4. Amoxicillin suspension\# & $62.5 \%$ & $100.0 \%$ & Available & $5.6 \%$ & $0.0 \%$ & N.A \\
\hline 5. Amoxicillin + clavulanic acid & $31.3 \%$ & $14.3 \%$ & N.A & $58.3 \%$ & $66.7 \%$ & Available \\
\hline \multicolumn{7}{|l|}{ Syrup\$ } \\
\hline 6. Ampicillin suspension\# & $25.0 \%$ & $0.0 \%$ & N.A & $2.8 \%$ & $0.0 \%$ & N.A \\
\hline 7. Azithromycin@ & $0.0 \%$ & $14.3 \%$ & Available & $2.8 \%$ & $0.0 \%$ & N.A \\
\hline 8. Benzathine Penicillin Powder\# & $0.0 \%$ & $0.0 \%$ & N.A & $0.0 \%$ & $0.0 \%$ & N.A \\
\hline 9. Cefixime\$ & $21.9 \%$ & $14.3 \%$ & N.A & $25.0 \%$ & $66.7 \%$ & Available \\
\hline 10. Ceftriaxone injection@* & $0.0 \%$ & $57.1 \%$ & Available & $0.0 \%$ & $0.0 \%$ & N.A \\
\hline 11. Cefuroxime axetil@* & $43.8 \%$ & $71.4 \%$ & N.A & $47.2 \%$ & $66.7 \%$ & N.A \\
\hline 12. Cefuroxime suspension@* & $0.0 \%$ & $28.6 \%$ & N.A & $0.0 \%$ & $0.0 \%$ & N.A \\
\hline 13.Cephalexin\#* & $43.8 \%$ & $71.4 \%$ & N.A & $19.4 \%$ & $33.3 \%$ & N.A \\
\hline 14. Cephalexin syrup\#* & $53.1 \%$ & $14.3 \%$ & Available & $8.3 \%$ & $0.0 \%$ & N.A \\
\hline 15. Ciprofloxacin\# & $37.5 \%$ & $100.0 \%$ & Available & $72.2 \%$ & $100.0 \%$ & Available \\
\hline 16. Co-trimoxazole suspension\# & $56.3 \%$ & $85.7 \%$ & Available & $2.8 \%$ & $0.0 \%$ & N.A \\
\hline 17. Doxycycline\# & $50.0 \%$ & $71.4 \%$ & Available & $69.4 \%$ & $100.0 \%$ & Available \\
\hline 18. Erythromycin powder for suspension\# & $40.6 \%$ & $42.9 \%$ & Available & $0.0 \%$ & $0.0 \%$ & N.A \\
\hline 19. Erythromycin stearate\# & $43.8 \%$ & $57.1 \%$ & Available & $0.0 \%$ & $0.0 \%$ & N.A \\
\hline 20. Gentamicin eye drops@ & $59.4 \%$ & $71.4 \%$ & Available & $11.1 \%$ & $33.3 \%$ & N.A \\
\hline 21. Gentamicin injection@ & $3.1 \%$ & $28.6 \%$ & Available & $0.0 \%$ & $0.0 \%$ & N.A \\
\hline 22. Norfloxacin\# & $84.4 \%$ & $85.7 \%$ & Available & $2.8 \%$ & $0.0 \%$ & N.A \\
\hline 23. Ofloxacin@ & $37.5 \%$ & $71.4 \%$ & Available & $47.2 \%$ & $66.7 \%$ & Available \\
\hline 24. Roxithromycin\# & $40.6 \%$ & $71.4 \%$ & N.A & $8.3 \%$ & $0.0 \%$ & N.A \\
\hline
\end{tabular}

\$Not in the Delhi State EML 2007 for Hospitals and dispensaries.

\# For primary care (dispensaries) Delhi State EML2007.

\#* Reserve antibiotics for restricted use in primary care.

@Antibiotics for hospital; these are in addition to antibiotics for primary care facilities.

* Reserve antibiotics to be used only in case of significant resistance to other antibiotics.

Antibiotics with mainly one trade name version availability A few antibiotics were generally available at both retail pharmacies and chain pharmacies with only one trade name which was usually the most popular brand name. These antibiotics were: ceftriaxone injection, cefuroxime suspension, cephalexin, cephalexin syrup, co-trimoxazole suspension, erythromycin stearate, gentamicin eye drops, gentamicin injection, norfloxacin, and roxithromycin.

\section{Price variations for few antibiotics in public and private sector}

We expect medicines to be more costly in private retail sector than the public procurement price. For few antibiotics the price variations was high as could be seen in Tables 4 and 8 . It was found that median MPR of lowest- priced generic (LPG) in private sector for cefuroxime suspension and cephalexin syrup were seven times; amoxicillin500 mg, amoxicillin $250 \mathrm{mg}$, cefuroxime were five times; and for cephalexin 6.5 times higher in the private retail sector as compared to median MPR for public procurement price.

Price and availability of high-end antibiotics surveyed Availability and price of surveyed high-end antibiotics at tertiary and secondary care facilities of public sector

All five procurement agencies were procuring or had fixed the rates for vancomycin and meropenam injection (Table 9). For the two oral antibiotics, gemifloxacin and moxifloxacin tablets procurement price was available 
Table 7 Availability of surveyed antibiotics in facilities surveyed in three tertiary care facilities of federal government in Delhi, India

\begin{tabular}{|c|c|c|c|c|}
\hline Medicines & $\mathrm{CGH}(\mathrm{n}=3)$ & LH & RML & SH \\
\hline 1. Amoxicillin + clavulanic acid & $66.7 \%$ & Available & N.A & Available \\
\hline 2. Amoxicillin 250 & $100.0 \%$ & Available & Available & Available \\
\hline 3. Amoxicillin 500 & $33.3 \%$ & Available & N.A & N.A \\
\hline 4. Amoxicillin suspension & $33.3 \%$ & Available & N.A & N.A \\
\hline 5. Amoxicillin + clavulanic acid Syrup & N.A & N.A & N.A & N.A \\
\hline 6. Ampicillin suspension & N.A & N.A & N.A & N.A \\
\hline 7. Azithromycin & $33.3 \%$ & Available & N.A & N.A \\
\hline 8. Benzathine Penicillin Powder & $66.7 \%$ & N.A & Available & Available \\
\hline 9. Cefixime & N.A & N.A & N.A & N.A \\
\hline 10. Ceftriaxone injection & $100.0 \%$ & Available & Available & Available \\
\hline 11. Cefuroxime axetil & N.A & N.A & N.A & N.A \\
\hline 12. Cefuroxime suspension & N.A & N.A & N.A & N.A \\
\hline 13. Cephalexin & $33.3 \%$ & N.A & Available & N.A \\
\hline 14. Cephalexin syrup & $33.3 \%$ & Available & N.A & N.A \\
\hline 15. Ciprofloxacin & $100.0 \%$ & Available & Available & Available \\
\hline 16. Co-trimoxazole suspension & $66.7 \%$ & Available & Available & N.A \\
\hline 17. Doxycycline & $33.3 \%$ & Available & N.A & N.A \\
\hline 18. Erythromycin powder for suspension & $66.7 \%$ & Available & Available & N.A \\
\hline 19. Erythromycin stearate & $100.0 \%$ & Available & Available & Available \\
\hline 20. Gentamicin eye drops & $66.7 \%$ & Available & N.A & Available \\
\hline 21. Gentamicin injection & $100.0 \%$ & Available & Available & Available \\
\hline 22. Norfloxacin & $100.0 \%$ & Available & Available & Available \\
\hline 23. Ofloxacin & $66.7 \%$ & Available & Available & N.A \\
\hline 24. Roxithromycin & N.A & N.A & N.A & N.A \\
\hline
\end{tabular}

CGH Central Government Hospitals.

LH Lady Hardinge Medical College \& Associated Hospitals.

RML Ram Manohar Lohia Hospital.

SH Safdarjung Hospital.

only for MCD though these were not available in their hospitals during the survey. Colistin injection was not procured by any agency. All five tertiary care hospitals had one or more surveyed antibiotics (Table 10). Out of the ten secondary care hospitals, two of Delhi government and one from MCD had no surveyed high-end antibiotics. The availability pattern indicates that the most common high-end antibiotic available in the hospitals is ceftazidime injection followed by meropenam and vancomycin injection.

Availability and price of surveyed high-end antibiotics in private sector At private retail pharmacies the availability of high-end antibiotics was poor (Table 10). Still meropenam injection was available at 13 pharmacies and gemifloxacin and moxiflocin tablets were available at 15 and 16 pharmacies out of 40 surveyed retail pharmacies. Compared to retail pharmacies, availability of high-end antibiotics was better at chain pharmacies moxifloxacin, gemifloxacin, and meropenam injection being available at $72.5 \%, 50.0 \%$, and $52.5 \%$ of these pharmacies. Prices of these antibiotics were similar to the prices available at retail pharmacies, except that two versions (trade names) of moxifloxacin were available at five chain pharmacies.

\section{Discussion}

This survey has provided a snap shot of availability of various antibiotics in the community in Delhi in both the public and private sectors. The methodology used for the survey is a standardized methodology for measuring access to essential medicines. Results from these WHO/HAI medicine price surveys are used for situation analysis and to plan interventions to improve access to essential medicines for global population [19-21].

Despite the strengths, the WHO/HAI methodology has a few limitations. First, availability and price are determined for a specific list of survey medicines, and do 
Table 8 Median price ratio, median unit price in local currency and availability of surveyed antibiotics at private retail pharmacies

\begin{tabular}{|c|c|c|c|c|c|c|c|}
\hline No. & Antibiotic name & $\begin{array}{l}\text { Medicine } \\
\text { type }\end{array}$ & $\begin{array}{l}\text { Median price ratio } \\
\text { (MPR) }\end{array}$ & Min & Max & $\begin{array}{c}\% \text { of facilities with } \\
\text { antibiotic }\end{array}$ & $\begin{array}{l}\text { Median unit price in } \\
\text { INR }\end{array}$ \\
\hline \multirow[t]{2}{*}{1} & Amoxicillin + Clavulanic acid & Highest Price & 4.83 & 0.48 & 4.83 & $95.0 \%$ & 40.17 \\
\hline & Amoxiciilin + Clavulanic acid & Lowest Price & 1.44 & 0.50 & 4.83 & $100.0 \%$ & 11.99 \\
\hline \multirow[t]{3}{*}{2} & Amoxicillin & Brand & N.A & N.A & N.A & $0.0 \%$ & N.A \\
\hline & Amoxicillin & Highest Price & 7.45 & 7.21 & 7.46 & $95.0 \%$ & 9.65 \\
\hline & Amoxicillin & Lowest Price & 7.21 & 5.05 & 7.45 & $97.5 \%$ & 9.33 \\
\hline \multirow[t]{2}{*}{3} & Amoxicillin 250 & Highest Price & 7.73 & 7.20 & 7.73 & $72.5 \%$ & 5.90 \\
\hline & Amoxicillin 250 & Lowest Price & 5.50 & 4.28 & 7.73 & $92.5 \%$ & 4.20 \\
\hline \multirow[t]{3}{*}{4} & Amoxicillin suspension & Brand & N.A & N.A & N.A & $0.0 \%$ & N.A \\
\hline & Amoxicillin suspension & Highest Price & 7.02 & 3.64 & 7.02 & $57.5 \%$ & 1.41 \\
\hline & Amoxicillin suspension & Lowest Price & 4.55 & 3.28 & 7.04 & $95.0 \%$ & 0.91 \\
\hline \multirow[t]{2}{*}{5} & $\begin{array}{l}\text { Amoxicillin + Clavulanic acid } \\
\text { Syrup }\end{array}$ & Highest Price & * & & & $62.5 \%$ & 3.64 \\
\hline & $\begin{array}{l}\text { Amoxicillin + Clavulanic acid } \\
\text { Syrup }\end{array}$ & Lowest Price & * & & & $92.5 \%$ & 1.58 \\
\hline \multirow[t]{2}{*}{6} & Ampicillin Suspension & Highest Price & $\#$ & & & $2.5 \%$ & \\
\hline & Ampicillin Suspension & Lowest Price & $\#$ & & & $2.5 \%$ & \\
\hline \multirow[t]{2}{*}{7} & Azithromycin & Highest Price & 2.06 & 1.42 & 2.16 & $95.0 \%$ & 30.83 \\
\hline & Azithromycin & Lowest Price & 1.57 & 1.14 & 2.06 & $100.0 \%$ & 23.50 \\
\hline \multirow[t]{2}{*}{8} & Benzathine Penicillin Powder & Highest Price & - & - & - & $0.0 \%$ & - \\
\hline & Benzathine Penicillin Powder & Lowest Price & - & - & - & $0.0 \%$ & - \\
\hline \multirow[t]{2}{*}{9} & Cefixime & Highest Price & 2.53 & 1.74 & 2.55 & $80.0 \%$ & 19.81 \\
\hline & Cefixime & Lowest Price & 1.26 & 0.87 & 2.56 & $97.5 \%$ & 9.90 \\
\hline \multirow[t]{3}{*}{10} & Ceftriaxone injection & Brand & N.A & N.A & N.A & $0.0 \%$ & N.A \\
\hline & Ceftriaxone injection & Highest Price & $\#$ & & & $2.5 \%$ & \\
\hline & Ceftriaxone injection & Lowest Price & 2.24 & 1.95 & 2.24 & $47.5 \%$ & 69.00 \\
\hline \multirow[t]{2}{*}{11} & Cefuroxime axetil & Highest Price & 5.73 & 3.59 & 5.73 & $55.0 \%$ & 43.10 \\
\hline & Cefuroxime axetil & Lowest Price & 3.23 & 1.40 & 5.73 & $90.0 \%$ & 24.30 \\
\hline \multirow[t]{2}{*}{12} & Cefuroxime Suspension & Highest Price & $\#$ & & & $2.5 \%$ & \\
\hline & Cefuroxime Suspension & Lowest Price & 3.16 & 2.41 & 3.51 & $55.0 \%$ & 4.33 \\
\hline \multirow[t]{2}{*}{13} & Cephalexin & Highest Price & 5.62 & 5.54 & 5.66 & $32.5 \%$ & 16.86 \\
\hline & Cephalexin & Lowest Price & 5.40 & 3.23 & 5.62 & $65.0 \%$ & 16.20 \\
\hline \multirow[t]{2}{*}{14} & Cephalexin Syrup & Highest Price & 5.53 & 4.59 & 5.53 & $22.5 \%$ & 2.27 \\
\hline & Cephalexin Syrup & Lowest Price & 4.79 & 1.55 & 5.53 & $50.0 \%$ & 1.97 \\
\hline \multirow[t]{3}{*}{15} & Ciprofloxacin & Brand & N.A & N.A & N.A & $0.0 \%$ & N.A \\
\hline & Ciprofloxacin & Highest Price & 6.78 & 6.73 & 7.28 & $85.0 \%$ & 9.27 \\
\hline & Ciprofloxacin & Lowest Price & 3.55 & 2.40 & 6.79 & $100.0 \%$ & 4.85 \\
\hline \multirow[t]{3}{*}{16} & Co-trimoxazole suspension & Brand & \# & & & $5.0 \%$ & \\
\hline & Co-trimoxazole suspension & Highest Price & $\#$ & & & $0.0 \%$ & \\
\hline & Co-trimoxazole suspension & Lowest Price & 1.29 & 0.83 & 1.32 & $77.5 \%$ & 0.24 \\
\hline \multirow[t]{3}{*}{17} & Doxycycline & Brand & & & & $0.0 \%$ & \\
\hline & Doxycycline & Highest Price & 9.30 & 1.80 & 14.09 & $55.0 \%$ & 4.86 \\
\hline & Doxycycline & Lowest Price & 1.82 & 1.50 & 14.09 & $97.5 \%$ & 0.95 \\
\hline 18 & $\begin{array}{l}\text { Erythromycin powder for } \\
\text { suspension }\end{array}$ & Highest Price & 0.94 & 0.94 & 0.94 & $15.0 \%$ & 0.50 \\
\hline
\end{tabular}


Table 8 Median price ratio, median unit price in local currency and availability of surveyed antibiotics at private retail pharmacies (Continued)

\begin{tabular}{|c|c|c|c|c|c|c|c|}
\hline & $\begin{array}{l}\text { Erythromycin powder for } \\
\text { suspension }\end{array}$ & Lowest Price & 0.94 & 0.65 & 0.94 & $55.0 \%$ & 0.50 \\
\hline \multirow[t]{2}{*}{19} & Erythromycin Stearate & Highest Price & 3.48 & 2.75 & 3.48 & $35.0 \%$ & 4.81 \\
\hline & Erythromycin Stearate & Lowest Price & 2.75 & 2.03 & 3.48 & $82.5 \%$ & 3.81 \\
\hline \multirow[t]{3}{*}{20} & Gentamicin eye drops & Brand & $\#$ & & & $5.0 \%$ & \\
\hline & Gentamicin eye drops & Highest Price & $\#$ & & & $2.5 \%$ & \\
\hline & Gentamicin eye drops & Lowest Price & 0.97 & 0.53 & 1.06 & $65.0 \%$ & 1.57 \\
\hline \multirow[t]{2}{*}{21} & Gentamicin injection & Highest Price & 1.92 & 1.76 & 2.15 & $15.0 \%$ & 3.83 \\
\hline & Gentamicin injection & Lowest Price & 1.84 & 1.51 & 1.96 & $57.5 \%$ & 3.66 \\
\hline \multirow[t]{2}{*}{22} & Norfloxacin & Highest Price & $\#$ & & & $5.0 \%$ & \\
\hline & Norfloxacin & Lowest Price & 4.72 & 2.04 & 4.77 & $95.0 \%$ & 4.85 \\
\hline \multirow[t]{2}{*}{23} & Ofloxacin & Highest Price & 5.22 & 2.74 & 5.70 & $92.5 \%$ & 8.81 \\
\hline & Ofloxacin & Lowest Price & 2.74 & 1.48 & 5.70 & $97.5 \%$ & 4.62 \\
\hline \multirow[t]{2}{*}{24} & Roxithromycin & Highest Price & * & & & $17.5 \%$ & 7.80 \\
\hline & Roxithromycin & Lowest Price & * & & & $92.5 \%$ & 7.80 \\
\hline
\end{tabular}

* MSH price is not available therefore MRP cannot be calculated.

\# MRP is not calculated if the antibiotic is not available at minimum of 4 outlets.

$N . A$ The brand version of that particular antibiotic is not available in India.

INR Indian Rupees (Local currency).

not account for alternate dosage forms of these medicines or therapeutic alternates. Availability data only refer to the day of data collection at each facility and might not indicate average availability of medicines over time. However, since the survey was done in several facilities over a period of time (2-3 months), the data provide a reasonable estimate of the overall situation and are indicative of the real-life situation faced by the patients on a daily basis. For this survey, data from 68 public primary care and 10 public secondary care facilities, and 80 private pharmacies was collected over a period of three months. It is only for an individual tertiary care facility $(n=5)$ that the availability reported is for one particular day only. The list of antibiotics surveyed for the present survey included those commonly used in both public and private sector as determined from our previous work on trends of antibiotic used in the community in Delhi [11] and also the strength and dosage form as mentioned in the Delhi state EML [18].

It is generally agreed that rapidly increasing antimicrobial resistance is due to inappropriate use of antibiotics. There are many forms of inappropriate use, for example

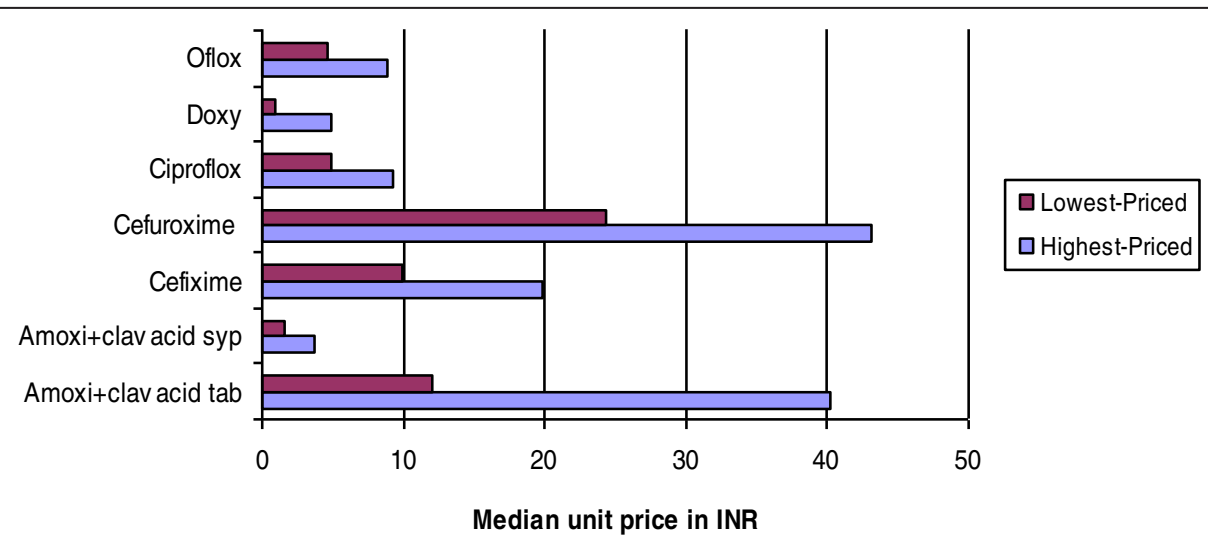

Figure 1 Price variation for a few antibiotics in the highest-priced and lowest-priced generic available at private retail pharmacies. Oflox = Ofloxacin; Doxy = Doxycycline; Ciproflox-Ciprofloxacin; Amoxi + clav = Amoxicillin + clavulanic acid; INR - Indian Rupees (Local currency) 


\section{Table 9 Antibiotic unit price in local currency (INR) for surveyed high-end antibiotics in public and private sector}

\begin{tabular}{|c|c|c|c|}
\hline $\begin{array}{l}\text { Antibiotic } \\
\text { name }\end{array}$ & $\begin{array}{l}\text { Public sector } \\
\text { procurement price } \\
\text { (procurement } \\
\text { agency) }\end{array}$ & $\begin{array}{c}\text { Private sector } \\
\text { (median unit } \\
\text { price at retail } \\
\text { pharmacies) }\end{array}$ & $\begin{array}{c}\text { Private sector } \\
\text { (median unit } \\
\text { price at chain } \\
\text { pharmacies) }\end{array}$ \\
\hline \multirow{2}{*}{$\begin{array}{l}\text { Cefepime } 1 \mathrm{~g} \\
\text { Inj }\end{array}$} & 65.52 (MCD), & \multirow[t]{2}{*}{-} & \multirow[t]{2}{*}{145.00} \\
\hline & 80.22 (CG1) & & \\
\hline \multirow{3}{*}{$\begin{array}{l}\text { Ceftazidime } \\
1 \mathrm{~g} \text { vial }\end{array}$} & 30.75 (CPA) & \multirow[t]{3}{*}{-} & \multirow[t]{3}{*}{416.70} \\
\hline & 32.80 (CG1) & & \\
\hline & 37.85 (CG2) & & \\
\hline $\begin{array}{l}\text { Colistin } \\
1000000 \text { units/ } \\
\text { vial }\end{array}$ & - & - & - \\
\hline $\begin{array}{l}\text { Gemifloxacin } \\
320 \text { mg tab/ } \\
\text { cap }\end{array}$ & 15.27 (MCD) & 14.90 & 14.90 \\
\hline $\begin{array}{l}\text { Imipenem + } \\
\text { cilastin }\end{array}$ & 386.98 (CG2) & - & 1200.00 \\
\hline $\begin{array}{l}500 \mathrm{mg}+ \\
500 \mathrm{mg} \operatorname{lnj}\end{array}$ & $567.00(\mathrm{CG} 1)$ & & \\
\hline \multirow{6}{*}{$\begin{array}{l}\text { Meropenem } \\
500 \text { mg Inj }\end{array}$} & 365.54 (MSO) $1 \mathrm{~g}$ inj & \multirow[t]{6}{*}{1347.00} & \multirow[t]{6}{*}{1347.00} \\
\hline & 1083.00 (MCD) $1 \mathrm{~g}$ inj & & \\
\hline & 1606.50 (CG2) $1 \mathrm{~g}$ inj & & \\
\hline & 1662.20 (CG1) & & \\
\hline & 850.50 (CPA) 500 mg; & & \\
\hline & $1606.001 \mathrm{~g}$ inj & & \\
\hline $\begin{array}{l}\text { Moxifloxacin } \\
400 \mathrm{mg} \text { tab/ } \\
\text { cap }\end{array}$ & 29.60 (MCD) & 69.55 & $69.55 \& 83.60$ \\
\hline \multirow{4}{*}{$\begin{array}{l}\text { Vancomycin } \\
500 \text { mg inj }\end{array}$} & 56.70 (MSO) & \multirow[t]{4}{*}{-} & \multirow[t]{4}{*}{ - } \\
\hline & 58.80 (CPA \& CG1) & & \\
\hline & 64.67 (MCD) & & \\
\hline & 65.45 (CG2) & & \\
\hline
\end{tabular}

INR Indian Rupees (Local currency).

unnecessary use of antibiotics, failure to prescribe ac cording to guidelines or non-availability of standard treatment guidelines, non-availability of appropriate antibiotics, availability of antibiotics without prescription, inappropriate self-medication and non-adherence to prescribed dosing schedules by patients [22]. We found in this survey that many newer antibiotics which were not in the list of Delhi state EML for primary care were available at primary care facilities of both Delhi government (GNCT, Delhi) and MCD run facilities. The survey revealed that all antibiotics on the list of Delhi state EML, even those were supposed to be reserve antibiotics for hospitals like cefuroxime, were available in dispensaries (Primary care facilities) of Delhi government and MCD. Three antibiotics surveyed, namely, amoxicillin + clavulanic acid tablet and syrup and cefixime, were not in the Delhi state EML of 2007 (used at the time of the survey) and we did not get procurement price for them from CPA-GNCT, Delhi. However, they were all available at primary care and secondary care facilities of GNCT, Delhi and MCD. Although, the revised Delhi state EML of 2010 [23] has these three antibiotics, procurement at the time of the survey did not use this list and it would seem that these antibiotics were procured following some other mechanism. Our earlier surveys conducted in GNCT, Delhi primary care also found that newer antibiotics meant for hospital use were available at primary care and were frequently used by the doctors $[11,12,24]$. The present survey also revealed that all antibiotics on the Delhi state EML for hospitals, even those for in-patients, were also available in the dispensaries (primary care). One procurement officer in CPA department of GNCT Delhi stated that all procured antibiotics are distributed to the dispensaries and that the Delhi state EML for dispensaries is not used for distribution. Unfortunately MCD does not have an EML and no separate lists for primary care, secondary care and tertiary care facilities.

Unnecessary or inappropriate use of antibiotics must be curbed immediately. Inappropriate availability will lead to inappropriate use. The next step is to have the national or local antibiotic policy including the development of an appropriate EML by level of facility, and monitoring to ensure compliance of procurement and supply with the EML [25]. Antibiotics should be available for use at the public sector according to standard treatment guidelines and the essential medicines list. Findings of this survey clearly reveal that though the Delhi state government (GNCT, Delhi) did have an EML, it was not followed for procurement and distribution to primary care. The other two agencies, MCD and facilities of central government had a procurement list which differed from the Delhi state EML and which may not have been developed according to patient need. Unlike a procurement list, development of an EML requires a committee of expert(s) who clearly understand the concept and importance of essential medicines and will prepare and revise the EML including antibiotics on the basis of essential medicine concepts [26]. Therefore, it is recommended that all providers should follow the essential medicine concept and that the EML be adapted to the differing medicines needs in primary care and tertiary care health care.

It is important to implement the EML and ensure that procurement and distribution of medicines (antibiotics) follow the EML according to various level of health care. None of the antibiotics which were meant for primary care (dispensaries) had 100\% availability or were available at all the surveyed facilities. Two antibiotics, amoxicillin500 $\mathrm{mg}$ and norfloxacin were available between 
Table 10 Availability of surveyed high-end antibiotics at secondary care and tertiary care public facilities and at private sector facilities

\begin{tabular}{lccc}
\hline Antibiotic name & $\begin{array}{c}\text { Public sector } \\
(\mathbf{n}=\mathbf{1 5})\end{array}$ & $\begin{array}{c}\text { Retail } \\
\text { pharmacies } \\
(\mathbf{n}=\mathbf{4 0})\end{array}$ & $\begin{array}{c}\text { Chain } \\
\text { pharmacies } \\
(\mathbf{n}=\mathbf{4 0})\end{array}$ \\
\hline Cefepime 1 g Inj & $20.0 \%$ & $0.0 \%$ & $10.0 \%$ \\
Ceftazidime 1 g vial & $73.3 \%$ & $5.0 \%$ & $20.0 \%$ \\
Colistin 1000000units/vial & $0.0 \%$ & $0.0 \%$ & $2.5 \%$ \\
Gemifloxacin 320 mg tab/cap & $0.0 \%$ & $37.5 \%$ & $50.0 \%$ \\
Imipenem + cilastin500mg & $13.3 \%$ & $0.0 \%$ & $22.5 \%$ \\
+ 500 mg Inj & & & \\
Meropenem 500 mg Inj & $60.0 \%$ & $32.5 \%$ & $52.5 \%$ \\
Moxifloxacin 400 mg tab/cap & $0.0 \%$ & $40.0 \%$ & $72.5 \%$ \\
Vancomycin 500 mg inj & $53.3 \%$ & $5.0 \%$ & $7.5 \%$ \\
\hline
\end{tabular}

80.0\%-85.0\%; for children amoxicillin250 and cotrimoxazole suspension was available at $71.9 \%$ and $56.3 \%$ facilities. Variety of antibiotics was available not according to the STGs or EML but according to the supply in the central store. Availability of antibiotics in secondary care hospitals was better than at tertiary care facilities. This finding indicates probably that smaller hospitals are managing their store and quantification better than the tertiary care hospitals in GNCT, Delhi.

Compared to GNCT-run facilities, access to antibiotics in MCD-run facilities was poor, none of the surveyed antibiotics having more than $80 \%$ availability at surveyed primary care facilities and only 4 antibiotics (ciprofloxacin, doxycycline, amoxicillin + clavulanic acid tablet and syrup) being available in $50 \%$ of facilities. While some essential antibiotics which should be available at primary care were poorly available, other second generation antibiotics like ofloxacin, cefuroxime, and cefixime had better availability than first generation antibiotics at primary care facilities. Availability of antibiotics at tertiary care facility was also poor and the only antibiotic available for children was amoxicillin + clavulanic acid syrup.

Findings of the survey provide a good baseline and evidence to administrators, managers, and policy makers to prepare and put in action essential medicine list and a good antibiotic policy [27]. A committee on EML and antibiotic policy should ensure that antibiotics are selected, procured, distributed and used more critically than has been the case up to the present time at different level of health care facilities.

For the public sector procurement price of surveyed antibiotics, it was strange to find that the older offpatented antibiotics viz., amoxicillin dosage forms and strength, ampicillin suspension, doxycycline and erythromycin had higher MPR than most of the newer antibiotics. This indicates the Indian manufacturers are selling off-patented antibiotics at a comparatively higher price than newer antibiotics. Variation in procurement price for different agencies was found and for quite a few of antibiotics, the procurement price of central government tertiary care facility doing independent procurement was much higher than other agencies. These findings confirm that pooled procurement decreases the procurement price [28,29] and local purchases of medicines done by individual facility cost higher [30]

At the private sector retail pharmacies, few antibiotics, like ampicillin suspension and benzathine penicillin powder for injection were either not available or available at one or two pharmacies only. This indicates that these antibiotics are generally not prescribed by doctors. Newer members from various classes, which are more expensive than the first generation of antibiotics (e.g. amoxicillin + clavulanic acid tablet and syrup, cefixime, cefuroxime, azithromycin, ofloxacin, roxithromycin), were always available at private pharmacies, as found in our previous surveys [11]. For a few antibiotics, only one trade name that is more costly (trade name or branded product) product was available.

These findings indicate that doctors are prescribing mainly the branded medicines that are pushed by the companies through their representatives and that pharmacists will stock those medicines for which they usually get prescriptions. In India generic substitution is legally not allowed. The brand name (trade name) written by a doctor can not be substituted with another. Some countries do have generic prescribing policies and/or generic substitution and such generic policies would be very efficient but it requires a high level of commitment from government and regulators. Excellent availability of antibiotics in the private retail pharmacies and chain pharmacies may be good news for patients from an access viewpoint. However, in India, like other developing countries, antibiotics may be obtained easily from private retail pharmacies without a prescription [31], contrary to the Indian government regulation and drug schedules. Indian pharmaceutical GMP guidelines are given in Drugs and Cosmetics Act 1940. Rules are given for pharmaceuticals and schedules are there to comply with the rules. "Schedule $\mathrm{H}$ " is a class of prescription drugs in India under Drugs and Cosmetics rules. Antibiotics come under 'Schedule H' and legally should not be dispensed without a prescription.

However, pharmacists themselves prescribe and dispense antibiotics usually for one or two days for conditions like acute diarrhea, sore throat etc. and follows the prescription of neighborhood practicing doctors [32]. Ministry of Health and Family Welfare, Government of India has recently prepared National Policy for Containment of Antimicrobial Resistance-India that covers a range of actions to be taken including introducing a 
separate schedule $\mathrm{H} 1$ for the sale of antibiotics. Under this schedule $\mathrm{H} 1$ third generation antibiotics and all newer antibiotic sales will be restricted [33]. However, this has yet to be implemented.

In the private sector availability of newer respiratory fluoroquinolones, gemifloxacin and moxifloxacin was good. Even meropenam injection was available at $32.5 \%$ retail pharmacies. Availability of these high-end antibiotics was better at retail chain pharmacies. Surprisingly, the retail pharmacies including the chain pharmacies where these antibiotics were available were not near the big hospitals but rather in the peri-urban areas or not so posh areas of Delhi.

\section{Conclusion}

Availability of some essential antibiotics is sub-optimal while other non-essential antibiotics are freely available in both the public and private sectors. Only one public sector agency had an EML which was only partially followed in procurement and distribution. Some newer reserve antibiotics are freely available in the private sector and priced lower than the older essential non-reserve antibiotics. Such a situation is likely to lead to inappropriate use of antibiotics and contribute to AMR. It is urgent that managerial and regulatory interventions be initiated to ensure that all public sector procurement follows an EML that has been developed in an evidence-based manner and that newer antibiotics are not available OTC in the private sector at inappropriately low prices.

\section{Competing interests}

All authors declare that they have no competing interests.

\section{Acknowledgment}

Authors would like to thank the government officials in the Director General Health Services, Central government; Directorate Health Services, GNCT, Delhi; DHA (Medical), MCD; the Medical Superintendants, doctors, and staff who cooperated in getting permissions and data collection. We wish to thank all the pharmacists who gave their precious time to provide data. We express our thankfulness to our excellent and diligent data collectors.

\section{Funding}

Funding for the survey was obtained from WHO, SEARO, New Delhi.

\section{Author details}

'Department of Pharmacology, V. P. Chest Institute, University of Delhi, Delhi, India. ${ }^{2}$ Essential Drugs and Other Medicines, World Health Organization, Regional Office of South East Asia, New Delhi, India.

Received: 27 June 2013 Accepted: 27 June 2013

Published: 12 August 2013

\section{References}

1. World Health organization: The evolving threats of antimicrobial resistance: options for action. Geneva, Switzerland: World Health Organization; 2012.

2. Goossens $\mathrm{H}$ : Antibiotic consumption and link to resistance. Clin Microbiol Infec 2009, 15:12-15.

3. Livermore DM: Bacterial resistance: origins, epidemiology, and impact. Clin Infect Dis 2003, 36:S11-S23.

4. Dukes MNG: Antibiotic use and public policy. Background document- A multidisciplinary meeting at the DAG Hammarskjold Foundation Uppsala. Sweden; 2004
5. Moslstad S, Erntell M, Hanberger H, Melander E, Norman C, Skoog G, et al: Sustained reduction of antibiotic use and low bacterial resistance: 10 year follow-up of the Swedish STRAMA programme. Lancet Infect Dis 2008, 8:125-132.

6. Coenen S, Ferech M, Haaijer-Ruskamp FM, Butler CC, Vander Stichele RH, Verheji TJ, Monnet, ESAC Project Group, et al: European Surveillance of antimicrobial consumption (ESAC): Quality indicators for outpatient antibiotic use in Europe. Qual Saf Health Care 2007, 16:440-445.

7. Metz-Gereck S, Maieron A, Straub R, Wienger P, Apfalter P, Mittermayer H: Ten years of antibiotic consumption in ambulatory care: Trends in prescribing practice and antibiotic resistance in Austria. BMC Infectious Dis 2009, 9:61

8. World Health Organization: Community-based surveillance of antimicrobial use and resistance in resource-constrained settings. Report on five pilot projects. Geneva, Switzerland: WHO; 2009. http://www.who.int/medicines/ publications/who_emp_2009.2/en/index.html.

9. Kotwani A, Holloway K, Chaudhury RR: Methodology for surveillance of antimicrobials use among out-patient in Delhi. Ind J Med Res 2009, 129:555-560

10. Pathak A, Mahadik K, Dhaneria SP, Sharma A, Eriksson B, Stalsby Lundborg C: Antibiotic prescribing in outpatients: hospital and seasonal variations in Ujjain. India. Scan J Inf Dis 2011, 43:479-488.

11. Kotwani A, Holloway K: Trends in antibiotic use among outpatients in New Delhi, India. BMC Infect Dis 2011, 11:99.

12. Kotwani A, Roy Chaudhury R, Holloway K: Antibiotic prescribing practices of primary care prescribers for acute diarrhoea in New Delhi India. Value Health 2012, 15:S116-S119.

13. Pathak D, Pathak A, Marrone G, Diwan V, Stålsby Lundborg C: Adherence to treatment guidelines for acute diarrhoea in children up to 12 years in Ujjain India - a cross-sectional prescription analysis. BMC Infec Dis 2011, 11:32

14. Measuring medicine prices, availability, affordability and price components. 2nd edition. Geneva: World Health Organization \& Health Action International; 2008. Available from: http://www.haiweb.org/medicineprices/ manual/documents.html

15. Singal G, Nanda A, Kotwani A: A comparative evaluation of price and quality of some branded versus branded-generic medicines of the same manufacturer in India. Ind J Pharmacol 2011, 43:131-136.

16. Madden J: What is a median price ratio? Essential Drug Monitor 2003, 33:17.

17. International Drug Price Indicator Guide. Cambridge, MA: Management Sciences for Health; 2011. http://erc.msh.org/dmpguide/index.cfm? search_cat=yes\&display=yes\&module=dmp\&language $=$ english $\& y e a r=2010$ Accessed July 13.

18. Essential Medicine List. Government of NCT Delhi; 2007. Available at http:// www.delhi.gov.in/DolT/Health/Druglist.pdf and http://www.scribd.com/doc/ 12401543/Drug-list Accessed July 13, 2011

19. Medicine prices, availability, affordability and price components surveys. Available at http://www.haiweb.org/medicineprices/.

20. Medicine procurement prices and processes in the United Nations Relief and Works Agency for Palestine Refugees in the Near East (UNRWA). UNRWA; 2011 Available at http://apps.who.int/medicinedocs/documents/s19903en/ s19903en.pdf.

21. The Global Partnership for Development: Making Rhetoric a Reality. Millennium Development Goal 8. MDG Gap Task Force Report; 2012. United Nations, New York, USA. Available at: http://www.un.org/millenniumgoals/ 2012_Gap_Report/MDG_2012Gap_Task_Force_report.pdf.

22. WHO: Medicines use in primary care in developing and transitional countries: fact book summarizing results from studies reported between 1990 and 2006. Geneva, Switzerland: World health organization; 2009. WHO/EMP/MAR/2009.

23. Essential Medicine List 2010. Government of NCT Delhi. Available at http:// www.delhi.gov.in/wps/wcm/connect/ ea065c0041c470dbab99fb08d0e5d97a/Final+2010+EML Final++2010+List. pdf?MOD=AJPERES\&CACHEID=ea065c0041 c470dbab99fb08d0e5d97a.

24. Wattal C, Raveendran R, Kotwani A, Sharma A, Bhandari SK, Sorensen TL, Holloway K: Establishing a new methodology for monitoring of antimicrobial resistance and use in the community in a resource poor-setting. Journal of Applied Therapeutic Research 2009, 7:37-45.

25. Holloway KA: Combating inappropriate use of medicines. Expert Rev Clin Pharmacol 2011, 4:335-348.

26. Hogerzeil $\mathrm{H}$ : The concept of essential medicines: lessons from rich countries. BMJ 2004, 329:1169-1172. 
27. Drew RH: Antimicrobial stewardship programs: How to start and steer a successful program. J Manag Care Pharm 2009, 15:S18-S23.

28. Kotwani $A$, Ewen $M$, Dey $D$, et al: Medicine prices and availability at six sites in India: using the WHO-HAl methodology. Ind J Med Res 2007, 125:645-654.

29. Chaudhury RR, Parameswar R, Gupta U, Sharma S, Tekur U, Bapna JS: Quality medicines for the poor: experience of the Delhi programme on rational use of drugs. HPP 2005, 20:124-136.

30. Kotwani A, Gurbani N, Sharma S, Chaudhury R: Insights for policymakers from a medicine price survey in Rajasthan. Ind I Med Res 2009, 129:451-454.

31. Radyowijati A, Haak H: Improving antibiotic use in low-income countries: an overview of evidence on determinants. Soc Sci Med 2003, 57:733-744.

32. Kotwani A, Wattal C, Katewa S, Joshi PC, Holloway K: Irrational use of antibiotics and role of pharmacists: an insight from a qualitative study in New Delhi, India. Journal of Clinical Pharmacy Therapeutics June 2012, 37:308-312.

33. Ministry of health \& family Welfare, Government of India: National Policy for containment of antimicrobial resistance-India; 2011. Available at http://nicd. nic.in/ab_policy.pdf Accessed on December 8, 2012.

doi:10.1186/2052-3211-6-6

Cite this article as: Kotwani and Holloway: Access to antibiotics in New Delhi, India: implications for antibiotic policy. Journal of Pharmaceutical Policy and Practice 2013 6:6.

\section{Submit your next manuscript to BioMed Central and take full advantage of:}

- Convenient online submission

- Thorough peer review

- No space constraints or color figure charges

- Immediate publication on acceptance

- Inclusion in PubMed, CAS, Scopus and Google Scholar

- Research which is freely available for redistribution 